\title{
Kadın Girişimciliği ve Cinsiyet-Rol Stereotipleri: Muş İli Örneği ${ }^{1}$
}

\author{
DOI: $10.26466 /$ opus.453934
}

\author{
$\underline{\text { Zeliha Tekin }}^{*}$ \\ *Dr. Öğr. Üyesi, Muş Alparslan Üniversitesi, Sosyal Bilimler M.Y.O., Muş/ Türkiye \\ E-Posta: z.tekin@alparslan.edu.tr \\ ORCID: $\underline{0000-0002-6283-0910}$
}

\section{Öz}

Kadın girişimciliği, kalkınma potansiyelinin artmasına ve daha fazla istihdam yaratılmasına olanak sağladığ̆ için üzerinde durulması ve geliştirilmesi gereken bir konudur. Bu bağlamda çalışmanın amacı, Muş'taki kadın girişimci adaylarının demografik özellikleri de dikkate alınarak girişimcilik profilinin ve faaliyet gösterdikleri alanların ortaya çıkarılması; hangi mesleklerde cinsiyet-rol stereotiplerin olduğunun belirlenmesidir. Çalışmanın evrenini, Muş'ta yerleşik olarak ikamet eden ve hane gelirine katkı sağlamak amacıyla evde para kazandıran işler (çocuk bakmak, el işi yapmak, peynir-süt, meyve-sebze satmak gibi) yapan kadınlar oluşturmuştur. Araştırmanın örneklemini ise tabakalı örnekleme yöntemi ile seçilen Muş merkez ve ilçelerinde ikamet eden 1000 kadın oluşturmaktadır. Araştırma sonucunda, kadınların imkân verildiğilyatırım ortamı oluşturulduğu takdirde iş yeri sahibi olmak istedikleri ortaya çıkmıştır. Çalışmada girişimcilikle ilgili bir eğitim almış olan kadınların girişimcilik eğilimlerinin, girişimciliğe yönelik genel eğilimlerinin, girişimciliğge yönelik algllanan sosyal norm düzeylerinin ve girişimciliğe yönelik tutumlarının dĭğer girişimcilik eğitimi almamış olanlara göre daha yüksek olduğu sonucuna varılmış; inşaat işleri, kaynakçılık, araba tamiri, marangozluk, elektrik işleri gibi mesleklerde cinsiyet-rol stereotiplerinin olduğu görülmüştür.

Anahtar Kelimeler: Girişimcilik, kadın girişimciliği, cinsiyet-rol stereotipleri, Muş

\footnotetext{
${ }^{1}$ Bu çalışma, Muş Alparslan Üniversitesi Bilimsel Araştırma Projeleri Koordinasyon Birimi tarafından desteklenmiştir (BAP proje no: BAP-17-SBMY-4901-01).
}

OPUS (c) Uluslararası Toplum Araştırmaları Dergisi-International Journal of Society Researches ISSN:2528-9527 E-ISSN : 2528-9535

http://opusjournal.net 


\title{
Women's Entrepreneurship and Sex-Role Stereo- types: Muş Province Example
}

\begin{abstract}
Women's entrepreneurship is a subject that needs to be emphasized and developed because it allows for the development of potential and the creation of more jobs. In this context, the aim of the study is to identify the entrepreneurship profile of women entrepreneur candidates in Mus and the areas in which they operate, taking into account the demographic characteristics of them, and determine the gender-role stereotypes in which professions they operate. The target population of the study is women who reside in Mus and make money at home to contribute to household income (such as looking after children, doing hand work, selling cheese, milk, fruits and vegetables). The sample of the research consists of 1000 women who reside in the Mus city center and districts selected by stratified sampling method. As a result of the research, it has been revealed that women want to have a place of business if they are allowed or an investment environment is created. The study also concluded that entrepreneurship trends, general trends towards entrepreneurship, perceived social norm levels of entrepreneurship and entrepreneurial attitudes of women who have an entrepreneurship training were higher than other status groups: it has been observed that there are gender stereotypes in occupations such as construction works, welding, car repair, carpentry and electrical works.
\end{abstract}

Keywords: Entrepreneurship, Women's Entrepreneurship, Sex-Role Stereotypes, Mus Province

OPUS (c) Uluslararası Toplum Araştırmaları Dergisi-International Journal of Society Researches ISSN:2528-9527 E-ISSN : 2528-9535

http://opusjournal.net 


\section{Giriş}

"Bir uygarlığın seviyesini ölçmek isterseniz derhal kadının hayat şartlarına bakın" demiş John Stuart Mill. Gerçekten de ekonomik gelişme ve sürdürülebilir kalkınma için kadınların iş gücüne katılımları büyük rol oynamaktadır. Kadınlar, ataerkil olan toplumsal yapıda yüklenmiş olduğu rol ve sorumluluklara (ev, eş, aile, ebeveyn bakımı) rağmen işsizlik, boşanma, esnek çalışma saatleri, gelişen teknolojinin beraberinde farklı iş seçenekleri getirmesi, devletin girişimcilik desteği sunması (kredi-hibe imkânı, ücretsiz girişimcilik eğitimi verme) gibi nedenlerden dolayı girişimci olmak istemektedirler.

\section{Kadın Girişimciliği}

Risk üstlenerek işgücü ve sermayesiyle yaratıcı projeler üretmek için işyerinin hukuki ve idari sorumluluğunu alarak işinin başında olan kadın, girişimci kadındır (Saray, 1993: 118). Kadınların işgücüne katılımı farklı şekillerde olmasına rağmen Türkiye ve dünyada cinsiyet-rol stereotiplerinin etkisiyle kadınların iş yaşamına katılımı belirli mesleklerde yoğunlaşmıştır (Güney, 2015: 241). Kadınların iş yaşamındaki konumuna ait değer ve tutumlar milli kültüre göre şekillenmektedir, geç kalmış olan ilerlemelerinin sebebi olarak da nüfusun genelince oluşturulan ve kabullenilen stereotipler gösterilmektedir (Herrera ve Lankau, 2005: 2033). Kadınlar daha çok öğretmenlik, sekreterlik, hemşirelik gibi mesleklerde yoğunlaşmışken; yöneticilik, avukatlık, mimarlık gibi meslekler erkek mesleği olarak görülmüştür (Güney, 2015: 241).

\section{Toplumsal Cinsiyet}

Cinsiyet (sex), doğuştan gelen, evrensel olan kadın ve erkek arasındaki biyolojik, genetik ve fizyolojik olarak belirlenen farklılıkları işaret eden bir kavramdır (Oakley, 1985: 16; Cherry, 2005: 157). Kadın ve erkeklerin kendine özgü olan farklılıkları/özellikleri eşitsizlik değil, yalnızca cinsiyet farkı oluşturmaktadır. 1960'lardan sonra gündeme gelen toplumsal cinsiyet (gender) kavramı ise, kadın ve erkeğin toplumdaki konumunu/statüsünü, statülerine uygun rollerini, görev ve sorumlulukların,, 
cinsiyetlerine yüklenen kimliklerine göre toplumun bireyi değerlendirip ona göre kadınsı ve erkeksi olarak değerlendirdiği sosyo-ekonomik bir sinıflandırmayı ifade etmektedir (Oakley, 1985: 16; Delphy, 1993: 3; Newman, 2002: 353). Bu tanımdan da anlaşılacağı üzere, toplumsal cinsiyet, tamamiyla biyolojik farklılıklarla tanımlanmakta olan cinsiyet kavramından farklı olarak, kültürel bir kavramdır (Bacacı ve Varoğlu, 2001: 323).

Tablo 1. Cinsiyet Rollerini Oluşturan Dişil ve Eril Özellikler

\begin{tabular}{|l|l|}
\hline KADIN & ERKEK \\
\hline Doğurabilir. Temel görev anneliktir & Zihinsel yaratıclı̆̆ı yüksektir \\
\hline Sevecen ve fedakârdır & Sorumluluk duygusu yüksektir \\
\hline Sessizdir & Yönetmeyi iyi bilir \\
\hline Detaycıdır & Soyut düşünme yeteneği gelişkindir \\
\hline Duygusaldır & Rasyoneldir \\
\hline Tek eşliliğe yatkındır & "Bir çiçekle bahar olmaz" der \\
\hline Dikkati insanlar ve ilişkilere yöneliktir & $\begin{array}{l}\text { Duygular ve ilişkilerden çok, teknolojiye } \\
\text { ve nesneler ilgi duyar }\end{array}$ \\
\hline Dedikoducudur & Saldırgandır \\
\hline Unutmayan bir beyin yapısına sahiptir & $\begin{array}{l}\text { Olayları, kişileri silen bir beyin yapısına } \\
\text { sahiptir }\end{array}$ \\
\hline Konuşkandır & Az konuşur- daha fazla dinler \\
\hline Depresyon riski yüksektir & $\begin{array}{l}\text { Kadınlara göre daha az depresyona } \\
\text { girmektedir }\end{array}$ \\
\hline Bağımlıdır & Bağımsızdır \\
\hline Kabullenicidir & Yargılayıcıdır \\
\hline Uyum sağlayan yapıdadır & Hükmedendir \\
\hline Yardımseverdir & Rekabetçidir \\
\hline Duyarlılık & Bireycilik \\
\hline Merhametlidir & Denetim altında tutmayı sever \\
\hline
\end{tabular}

Kaynak: Bora, 2008: 11; Navaro, 1997: 29; Bacact-Varoğlu, 2001: 324; www.sozcu.com.tr kaynaklarından derlenmiştir.

Tablo 1'deki cinsiyet özelliklerinden bazıları biyolojik, bazıları kültürün bize öğrettiği niteliklerdir. Cinsiyete yönelik özellikler, stereotipik cinsiyet davranışları içerisinde gözlenebilir. Örneğin, kadınlar stereotipik olarak, erkeklerden daha duygusaldır ve duygusal olarak başka insanlara bağımlı olmakta ve kendi ihtiyaçlarını eşinin/partnerinin ve çocuklarının ihtiyaçlarından ayırmakta zorluk çekmektedirler. Bu durumun 
sebebi bulanık ego sınırları ile şu şekilde açıklanmaktadır: Kadın, kendi ihtiyaçlarını başkalarının ihtiyaçlarından ayırt etmekte zorluk çeker; çünkü başarılı bir bireyselleşme döneminden geçmemiştir. Tersi durumda ise erkeklerin duygusal bağları daha zayıftır. Bu da erkeklerin daha iyi tanımlanmış ego sınırlarıyla ilgilidir ve erkekler kendi ihtiyaçlarıyla diğerlerinin ihtiyaçlarını ayırt etmekte zorluk çekmezler. Chodorow (1995) bu cinsiyet farklılıklarının değişmesi gerektiğini savunur. Çünkü söz konusu roller, kadınları diğerlerinin ihtiyaçları konusunda fazla hassas kılarken, erkekleri duygusal anlamda yetersiz bırakmaktadır (Zara ve Özdemir, 2013: 4).

\section{Cinsiyet-Rol Stereotipleri}

Toplumsal cinsiyet kavramının içinde barınan onun bir boyutunu ifade eden toplumsal cinsiyet rolleri, toplumsal-kültürel beklentiler sonucunda kadına ve erkeğe uygun görülen kişilik özellikleri ve davranışları içeren ve sonuçta toplum tarafından kalıp yargılara dönüştürülen rolleri ifade etmektedir. Bu feminen ve maskülen roller, cinsiyetten bağımsız olarak ifade edildiği gibi, içinde bulunduğu ortama göre de değişebilmektedir (Dökmen, 2004: 18). Cinsiyet rollerinin belirlenmesinde toplumsal yapıyı meydana getiren çeşitli öğeler/değerler etkendir. Annebaba, eş, öğretmenler, kitle iletişim araçları, sosyalleşmede etkili olduğu gibi kişinin toplumsal cinsiyet rollerinin belirlenmesinde de etkili olan öğelerdir (Ickes, 2014: 71; Seçgin ve Tural, 2011). Toplumsal yaşamdaki mesleklerin de dişil ve eril olarak ayrışması cinsiyet-rol stereotipi olarak ifade edilir. Örnek verilecek olursa inşaat işi, yönetim işleri, mühendislik, imalat gibi iler erkek işi olarak anılırken; hemşirelik, sekreterlik, eğitim danışmanlığı gibi işler kadın işi olarak görülür. Bu tarz bir stereotipsel ayrım ise iş yaşamında cinsiyet ayrımcılığını yansıtmaktadır (Gupta vd., 2009: 398-399).

\section{Metodoloji}

Metodoloji kısmında, çalışmanın bulgularına ve sonuçlarına yer verilmiştir. 


\section{Çalışmanın Amacı}

$\mathrm{Bu}$ araştırmanın amac, Muş'taki kadın girişimci adaylarının demografik özellikleri de dikkate alınarak girişimcilik profilinin ve faaliyet gösterdikleri alanların ortaya çlkarılması; hangi mesleklerde cinsiyet-rol stereotiplerin olduğunun belirlenmesi ve kadın girişimciliğinin artırılması yönünde çözüm önerilerinin sunulmasıdır.

\section{Araştırmanın Evreni ve Örneklemi}

$\mathrm{Bu}$ araştırmanın evrenini, Muş merkez ve ilçelerinde ikamet eden ve hane gelirine katkı sağlamak için ev içinde el işi yapan; yemek yapıp satan, yetiştirdiği meyve-sebzeyi satan; hayvanlarından sağladığı süt, yoğurt ve peyniri ev dişına satan; temizliğe giden, bakıcılık yapan kadınlar oluşturmuştur. Evreni 100.000 ve üzeri olan araştırmalarda örneklemin minimum seviyede 384 olması gerekmektedir (Sekeran, 1992: 253). Bu çalışmada da toplamda 1000 örneklem büyüklüğü olduğu için örneklemin evreni temsil ettiği doğrulanmıştır. 2016 yılında Muş ilinde kadın nüfusu 199.311'dir. Kadın nüfusuna göre bu çalışmanın örneklem dağılımı Tablo 2'de görüldüğü gibidir:

Tablo 2: Kadın nüfusuna göre bu çalışmanın örneklem dağılımı

\begin{tabular}{|l|l|l|l|}
\hline YER & NÜFUS & $\begin{array}{l}\text { NÜFUS / TOPLAM } \\
\text { NÜFUS }\end{array}$ & ÖRNEKLEM \\
\hline MERKEZ & 92811 & 0.4657 & 466 \\
\hline BULANIK & 39891 & 0.2001 & 200 \\
\hline MALAZGIRT & 25818 & 0.1295 & 130 \\
\hline VARTO & 15237 & 0.0764 & 76 \\
\hline HASKÖY & 12979 & 0.0651 & 65 \\
\hline KORKUT & 12575 & 0.0631 & 63 \\
\hline & TOPLAM=199.311 & & TOPLAM=1000 \\
\hline
\end{tabular}

Çalışmanın örnekleme yöntemi tabakalı örneklemedir. Tabakalı örnekleme evrendeki alt grupların evrendeki ağırlıkları oranında temsil edilmesine olanak sağlar. Bu şekilde toplam örneklem içinde her sınıf eşit düzeyde veya evrendeki oranı ölçüsünde temsil edilebilir. 


\section{Araştırmanın Yöntemi}

Anket tekniği bu çalışmada veri toplama tekniği olarak kullanılmıştır. Çalışmada, Uygun ve Güner'in (2016) literatür tarayarak oluşturduğu 4 boyutlu 17 ifadeli "Girişimcilik Eğilimi Ölçeği" kullanılmıştır. Anket soruları iki kısımdan oluşmaktadır. İlk kısımdaki sorular, açık uçlu ve çoktan seçmeli olup cevaplayıcıların demografik özelliklerini saptamayı amaçlamaktadır. İkinci kısımdaki sorular ise katılımcıların girişimcilik eğilimini ölçmeye yönelik olan ve 5'li Likert Ölçeği kullanılarak oluşturulan sorulardır.

\section{Bulgular}

Katılımcıların demografik özellikleri göz önünde tutularak girişimcilik eğilimlerinin ve cinsiyet-rol stereotiplerinin belirlenmeye çalışıldığ 1000 kadın üzerinde yürütülen anket çalışmasından elde edilen veriler SPSS 24.0 istatistik paket programı ile değerlendirilmiştir. Sonuçların elde edilmesinde Faktör Analizi, Kruskal Wallis H Testi ve Bonferroni Testi testinden yararlanılmıştır $(\mathrm{p}<0,05)$.

\section{Demografik Özelliklere İlişkin Bulgular}

Araştırma katılımcılarının demografik özelliklerine ilişkin veriler Tablo 3'de yer almaktadir.

Tablo 3. Katılımcıların Tanımlayıcı Özellikleri (N=1000)

\begin{tabular}{|c|c|c|c|}
\hline Değişkenler & Özellikler & $\mathrm{n}$ & $\%$ \\
\hline \multirow{5}{*}{ Yaş } & $18-29$ & 434 & 43,4 \\
\hline & $30-39$ & 263 & 26,3 \\
\hline & $40-49$ & 178 & 17,8 \\
\hline & $50-59$ & 67 & 6,7 \\
\hline & 59 ve üzeri & 58 & 5,8 \\
\hline \multirow{6}{*}{ Eğitim Durumu } & İlkokul & 406 & 40,6 \\
\hline & Ortaokul & 215 & 21,5 \\
\hline & Lise & 290 & 29,0 \\
\hline & Ön lisans & 52 & 5,2 \\
\hline & Lisans & 32 & 3,2 \\
\hline & Lisansüstü & 5 & 0,5 \\
\hline
\end{tabular}




\begin{tabular}{|c|c|c|c|}
\hline \multirow{2}{*}{ Medeni Durum } & Evli & 585 & 58,5 \\
\hline & Bekar & 415 & 41,5 \\
\hline \multirow{6}{*}{ İkamet Yeri } & Merkez & 466 & 46,6 \\
\hline & Varto & 76 & 7,6 \\
\hline & Malazgirt & 130 & 13,0 \\
\hline & Bulanık & 200 & 20,0 \\
\hline & Korkut & 63 & 6,3 \\
\hline & Hasköy & 65 & 6,5 \\
\hline \multirow{7}{*}{$\begin{array}{l}\text { Kazanç Sağlama } \\
\text { Amacıyla Evde Yapılan } \\
\text { İşler }\end{array}$} & El işi, örgü & 406 & 40,6 \\
\hline & Hayvan Ür. Satma & 119 & 11,9 \\
\hline & Tandır yapıp satma & 143 & 14,3 \\
\hline & Meyve-sebze satma & 41 & 4,1 \\
\hline & Temizlik, bakıcilık & 15 & 1,5 \\
\hline & Yemek yapıp satma & 72 & 7,2 \\
\hline & Diğer & 12 & 1,2 \\
\hline \multirow{2}{*}{$\begin{array}{l}\text { İşyeri Açmak İçin Yeter- } \\
\text { li Sermaye Sahibi Olma }\end{array}$} & Evet & 51 & 5,1 \\
\hline & Hayır & 949 & 94,9 \\
\hline \multirow{5}{*}{$\begin{array}{l}\text { Katılımcıların Evde } \\
\text { Çalışıp/Üretip Dışarıya } \\
\text { Satma Süresi }\end{array}$} & $1-5 \mathrm{y} 1 \mathrm{l}$ & 579 & 57,9 \\
\hline & 6-10 yil & 160 & 16,0 \\
\hline & $11-15$ yil & 100 & 10,0 \\
\hline & $16-20 \mathrm{y} 1 \mathrm{l}$ & 81 & 8,1 \\
\hline & 20 yıldan fazla & 80 & 8,0 \\
\hline \multirow{4}{*}{ Faaliyet Gösterilen Alan } & Hayvancilık & 124 & 12,4 \\
\hline & Tarım & 31 & 3,1 \\
\hline & El işi, imalat & 645 & 64,5 \\
\hline & Temizlik, bakıcılık & 48 & 4,8 \\
\hline \multirow{2}{*}{$\begin{array}{l}\text { Girişimcilik Kursuna } \\
\text { Gitme }\end{array}$} & Evet & 405 & 40,5 \\
\hline & Hayır & 595 & 59,5 \\
\hline \multirow{2}{*}{$\begin{array}{l}\text { Ailede Bir Girişimcinin } \\
\text { Varlığı }\end{array}$} & Evet & 276 & 27,6 \\
\hline & Hayır & 724 & 72,4 \\
\hline \multirow{10}{*}{$\begin{array}{l}\text { Muss'ta Kadınların } \\
\text { Çalışılamayacağı } \\
\text { Düşünülen Meslekler }\end{array}$} & Sekreterlik & 89 & 8,9 \\
\hline & İnşaat, araba tamiri & 805 & 80,5 \\
\hline & Fabrikada yapılan işler & 158 & 15,8 \\
\hline & Politika & 121 & 12,1 \\
\hline & Marangoz & 585 & 58,5 \\
\hline & Elektrik & 556 & 55,6 \\
\hline & Boyacılık & 499 & 49,9 \\
\hline & Pilotluk & 296 & 29,6 \\
\hline & İdari işler/yöneticilik & 103 & 10,3 \\
\hline & Polislik-bekçilik & 194 & 19,4 \\
\hline
\end{tabular}




\begin{tabular}{|c|c|c|c|}
\hline \multirow{10}{*}{$\begin{array}{l}\text { Muş'ta Kadınların } \\
\text { Çalışılabileceği } \\
\text { Düşünülen } \\
\text { Meslekler }\end{array}$} & Yönetici asistanlığ 1 & 657 & 65,7 \\
\hline & Öğretmenlik & 821 & 82,1 \\
\hline & Eczacılık & 713 & 71,3 \\
\hline & Doktorluk-hemşirelik & 754 & 75,4 \\
\hline & Aşçılık & 773 & 77,3 \\
\hline & Terzilik & 797 & 79,7 \\
\hline & Çiftçilik & 616 & 61,6 \\
\hline & Avukatlık & 634 & 63,4 \\
\hline & Bankacılık & 597 & 59,7 \\
\hline & Mühendislik & 547 & 54,7 \\
\hline \multirow{6}{*}{$\begin{array}{l}\text { Kadın Girişimci } \\
\text { Adayların Var } \\
\text { olduğunu Düşündüğüu } \\
\text { Sorunlar }\end{array}$} & Taciz & 314 & \\
\hline & $\begin{array}{l}\text { Aile Baskısı ve Destekten Yok- } \\
\text { sunluk }\end{array}$ & 608 & \\
\hline & $\begin{array}{l}\text { Yeterli Ĕ̆itim İmkanının Ol- } \\
\text { maması }\end{array}$ & 659 & \\
\hline & $\begin{array}{l}\text { Toplumsal Cinsiyet Eşitsizliğin } \\
\text { Yaşanması }\end{array}$ & 567 & \\
\hline & Maddi Kaynak Eksikliği & 706 & \\
\hline & Olumsuz Doğa Koşulları & 475 & \\
\hline
\end{tabular}

Tablo 3'de görüldüğü üzere, katılımcı kadınların çoğunluğu (434 kişi) 18-29 yaş aralığındadır ve yarıdan fazlası evlidir (585 kişi). Türkiye'deki kadın girişimciliği hakkında yorum yapabilmek için okullaşma oranının da dikkate alınması gerekmektedir. Katılımcılarının eğitim durumlarına bakıldığında çoğunluğun ilkokul mezunu olduğu görülmektedir (406 kişi). Katılımcıların hemen hemen hepsi (949 kişi) bir iş yeri açacak sermayeye sahip değildir. 1000 katılımcı kadından yalnızca 51'inin bir iş yeri açabilecek yeterli sermayesi vardır. Katılımcıların 405'i girişimcilik ile ilgili bir eğitim almışken; 595'i girişimcilik ile ilgili bir eğitim almamıştır ve 724'ünün ailesinde girişimci yokken 276'sının ailesinde girişimci vardır. Katılımcıların yarıdan fazlası (645 kişi) biçki-dikiş, halı dokuma, örgü yapma gibi el işleriyle uğraşmaktadır. $80 \mathrm{~km}$ uzunluk ve $30 \mathrm{~km}$ genişliğinde 165.000 hektar alanıla Türkiye'nin tek parça halinde olan üçüncü büyük ovası olan Muş Ovasının varlığına ve ekilebilir alanların fazlalığına rağmen ankete cevap veren kadınların yalnızca 31'i tarımla uğraşmakta; 124 kişi de hayvancılıkla ilgilenmektedir. Kadın girişimci adaylarının ankete verdikleri cevaplardan inşaat işleri, araba tamirciliği, 
marangozluk, elektrik işleri, boyacllık gibi işlerde (erkek mesleği olarak algılanma) ve de öğretmenlik, hemşirelik-doktorluk, aşçllık, terzilik, eczacılık, yönetici asistanlığı-sekreterlik (kadın mesleği olarak algılanma) cinsiyet-rol stereotiplerin var olduğu anlaşılmaktadır. Kadın girişimci adaylarının girişimcilik faaliyetleri açısından var olduğunu düşündüğü sorunların başında maddi kaynak yetersizliğinin gelmektedir (706 kişi). Ayrıca yeterli eğitim imkânlarının olmayışı (659 kişi), aile baskısı-aileden bir işyeri açmayla ilgili olarak yeterli desteğin alınamaması (608 kişi), cinsiyet eşitsizliğinin varlığı (567 kişi) gibi diğer olumsuz unsurların varlığı da göz ardı edilmemelidir.

\section{Faktör Analizi Bulgular}

Katılımcılardan elde edilen verilerin yapısal geçerliliğini saptamak amacıyla açıklayıcı faktör analizi yapılmıştır. Varimax döndürmesi sonuçlarında maddeler toplam 4 faktör altında toplanmıştır. Bu faktörler toplam varyansın \%81,844'ünü açıklamaktadır. Tablo 3'de görüldügü üzere birinci faktör olan "Girişimciliğe Yönelik Genel Eğilim" toplam varyansın \%30,042'sini, ikinci faktör "Girişimciliğe Yönelik Algılanan Sosyal Norm" \%18,377'sini, üçüncü faktör “Girişimciliğe Yönelik Algılanan Davranışsal Kontrol" \%17,029'unu ve dördüncü faktör "Girişimciliğe Yönelik Tutum" \%16,396'sını açıklamaktadır.

Tablo 4' de gösterilen araştırma modelinde yer alan ifadelerin faktör yükleri değerlerine bakıldığında, girişimciliğe yönelik genel eğiliminin faktör yüklerinin 0,592 ile 0, 829 değerleri arasında; girişimciliğe yönelik algılanan sosyal norma ait faktör yüklerinin 0,516 ile 812 değerleri arasında; girişimciliğe yönelik algılanan davranışsal kontrol faktörüne ait faktör yüklerinin 0.593 ile 0.696 değerleri arasında; girişimciliğe yönelik tutum faktörüne ait faktör yüklerinin ise 0,705 ile 0,797 değerleri arasinda olduğu görülmektedir. Faktör yüklerinin geneli bize, her bir faktördeki ifadelerin faktör yüklerinin oldukça yüksek olduğunu ve olması gerektiği gibi bir boyuttaki madde sayılarının 3'ten az olmadığını göstermektedir. 
Tablo 4. Girişimcilik Ĕ̆iliminin Boyutlarına Yönelik Faktör Analizi Sonuçları

\begin{tabular}{|c|c|c|c|}
\hline Boyutlar ve Ölçek Maddeleri & $\begin{array}{c}\text { Faktör } \\
\text { Yükleri* }\end{array}$ & $\begin{array}{l}\text { Açlklanan } \\
\text { Varyans }\end{array}$ & $\begin{array}{l}\text { Cronbach } \\
\text { Alpha }\end{array}$ \\
\hline Girişimciliğe Yönelik Genel Eğilim Boyutu & & \multirow{6}{*}{$\% 30,042$} & \multirow{6}{*}{0,919} \\
\hline $\begin{array}{l}\text { Gelecekte kendi işimi kurmak ve sürdürmek için çaba } \\
\text { gösteririm. }\end{array}$ & 0,829 & & \\
\hline Bir iş kurma üzerine ciddi ciddi kafa yorarım. & 0,752 & & \\
\hline Gelecekte kendi işimi kurma olasılığım çok yüksektir. & 0,622 & & \\
\hline $\begin{array}{l}\text { Gelecekte yeterli kaynak ve fırsat olursa kendi işimi } \\
\text { kurmayı çok istiyorum. }\end{array}$ & 0,592 & & \\
\hline $\begin{array}{l}\text { Şu an bir iş kurmak için kendimi tamamen hazır hisse- } \\
\text { diyorum. }\end{array}$ & 0,745 & & \\
\hline $\begin{array}{l}\text { Girişimciliğe Yönelik Algılanan Sosyal Norm } \\
\text { Boyutu }\end{array}$ & & \multirow{5}{*}{$\% 18,377$} & \multirow{5}{*}{0,885} \\
\hline Aile fertlerim kendi işimi kurma kararımı onaylıyorlar. & 0,708 & & \\
\hline $\begin{array}{l}\text { Arkadaşlarım kendi işimi kurma konusundaki kararımı } \\
\text { onaylıyorlar. }\end{array}$ & 0,516 & & \\
\hline $\begin{array}{l}\text { Toplumda kendi işine sahip olanların daha çok takdir } \\
\text { edildiği düşüncesindeyim. }\end{array}$ & 0,780 & & \\
\hline $\begin{array}{l}\text { Kendi işine sahip olanların daha itibarlı olduğu düşün- } \\
\text { cesindeyim. }\end{array}$ & 0,812 & & \\
\hline $\begin{array}{l}\text { Girişimciliğe Yönelik Algılanan Davranışsal } \\
\text { Kontrol Boyutu }\end{array}$ & & \multirow{5}{*}{$\% 17,029$} & \multirow{5}{*}{0,931} \\
\hline $\begin{array}{l}\text { Yeteneklerimin ve becerilerimin bir iş kurmak için } \\
\text { yeterli olduğu düşüncesindeyim. }\end{array}$ & 0,593 & & \\
\hline $\begin{array}{l}\text { Geçmiş deneyimlerimin bir iş kurmada önemli katkılar } \\
\text { sunacağı düşüncesindeyim. }\end{array}$ & 0,622 & & \\
\hline $\begin{array}{l}\text { Bir iş kurmak için ihtiyaç olan çabayı gösterme konu- } \\
\text { sunda kendime güveniyorum. }\end{array}$ & 0,668 & & \\
\hline $\begin{array}{l}\text { Bir iş kurmaya çalıştığımda başarı şansımın yüksek } \\
\text { olduğunu düşünmekteyim. }\end{array}$ & 0,696 & & \\
\hline Girişimciliğe Yönelik Tutum Boyutu & & \multirow{5}{*}{$\% 16,396$} & \multirow{5}{*}{0,942} \\
\hline $\begin{array}{l}\text { Kendi işimi kurmayı diğer kariyer fırsatlarından daha } \\
\text { fazla arzu etmekteyim. }\end{array}$ & 0,705 & & \\
\hline $\begin{array}{l}\text { Kendi işimi kurmaya çaba sergilendiğim sürece sorun } \\
\text { yaşamayacağım düşüncesindeyim. }\end{array}$ & 0,777 & & \\
\hline $\begin{array}{l}\text { Geleceğe yönelik öncelikli amacım, kendi işimi kur- } \\
\text { maktır. }\end{array}$ & 0,789 & & \\
\hline $\begin{array}{l}\text { Kendi işime sahip olmak düşüncesinden büyük haz } \\
\text { alıyorum. }\end{array}$ & 0,797 & & \\
\hline \multicolumn{3}{|c|}{ Genel Girişimcilik Eğilimi Ölçeği } & 0,972 \\
\hline * Rotasyon Yöntemi: Varimax & $\begin{array}{l}\text { Toplam } \\
\text { Varyans: }\end{array}$ & $\begin{array}{l}\text { Açıklanan } \\
81,844\end{array}$ & \\
\hline KMO = 0,965; $\chi 2(136)=18097,292 ;$ Bartlett Küreselli & esti $(p)=0$ & & \\
\hline
\end{tabular}


Çalışmanın KMO değeri 0,965 (iyi derecede yeterli) olduğundan dolayı örneklem yeterliliği faktör analizi yapmak için yeterli düzeydedir. Ayrıca Bartlett küresellik testi sonuçlarında görüldüğ̈̈ üzere elde edilen ki kare değeri kabul edilebilir seviyededir $(\chi 2(136)=18097,292 ; \mathrm{p}<0,01)$.

\section{Faktörlere Ait Normal Dağılım Testi Sonuçlan}

Likert tipi ölçek kullanılan anketlerde, çoğu zaman veriler normal dağılmamaktadır. Normal dağılıma uygunluk Q-Q Pilot çizimi ile incelenebilir (Chan, 2003: 280-285). Ayrıca, kullanılan verilerin normal dağılım göstermesi çarpıklık ve basıklık değerlerinin \pm 3 arasında olmasına bağl1dır (Shao, 2002). Ölçeğe ait çarpıklık değeri (istatistik değeri/Std. Hata)= 13,86, basıklık değeri (istatistik değeri/Std. Hata)= 1,61 olarak tespit edilmiş olup, belirlenen \pm 3 aralığında yer almadığı görülmüştür.

Tablo 5. Girişimcilik Ĕ̆ilimi Ölçeğinin Çarpıklık ve Basıklık Değerleri (Normallik)

\begin{tabular}{|l|l|l|l|}
\hline \multicolumn{2}{|c|}{} & İstatistik & Std. Hata \\
\hline \multirow{2}{*}{$\begin{array}{l}\text { Girişimcilik } \\
\text { Ĕ̈ilimi }\end{array}$} & Ortalama & 3,7389 &, 03550 \\
\cline { 2 - 4 } & Çarpıklık & $-1,067$ &, 077 \\
\cline { 2 - 4 } & Basıklık &, 249 &, 155 \\
\hline
\end{tabular}

Q-Q Plot çizimi aşağıda verilen şekildedir;

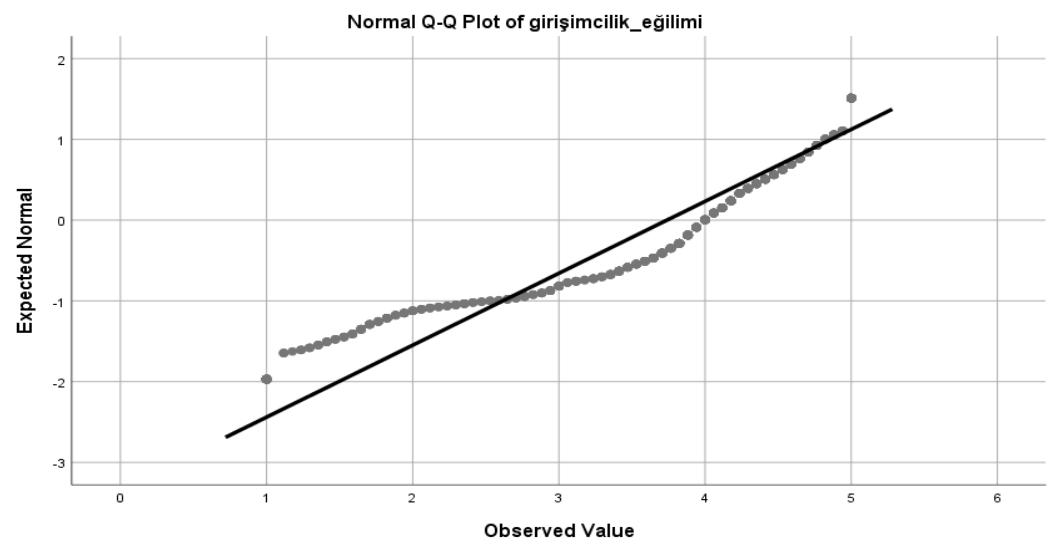

Şekil 1. Normal Dağılım Eğilimi Grafiği 
Bu duruma göre; ölçek normal dağılım göstermediği için istatistik değerlendirmelerde nonparametrik testler kullanılmıştır. Bunun için niceliksel verilerin karşılaştırılmasında iki grup arasındaki farkı MannWhitney U testi, ikiden fazla grup ortalamalarında karşılaştırmalarında Kruskal Wallis $\mathrm{H}$ testi uygulanmıştır. Varyans analizi ile test edilen verilerde farklı olan grubu bulmak için Bonferroni çoklu karşılaştırma testi yapılmıştır.

\section{Kruskal-Wallis H Testi ve Bonferroni Testi Bulgularn}

Araştırmaya dâhil olan kadın girişimci adaylarının girişimcilik eğilimi ölçeği ve alt boyutlarının eğitim durumuna göre farklılaşıp farklılaşmadığını belirlemek üzere, Kruskal Wallis $\mathrm{H}$ testi uygulanmıştır.

Tablo 6. Katılımcıların Tanıtıcı Özelliklerine Göre Girişimcilik Eğilimi Ölçeği ve Alt Boyutlarının Puanlarının Dağılımı

\begin{tabular}{|c|c|c|c|c|c|}
\hline \multirow{3}{*}{$\begin{array}{c}\text { Tanitıcı Özellik- } \\
\text { ler }\end{array}$} & \multicolumn{5}{|c|}{ Ölçek Alt Boyutları } \\
\hline & $\begin{array}{l}\text { Girişimcili- } \\
\text { ğe yönelik } \\
\text { genel eğilim }\end{array}$ & $\begin{array}{l}\text { Girişimcili- } \\
\text { ge yönelik } \\
\text { algılanan } \\
\text { sosyal norm }\end{array}$ & $\begin{array}{c}\text { Girişimcili- } \\
\text { ge yönelik } \\
\text { algılanan } \\
\text { davranışsal } \\
\text { kontrol } \\
\end{array}$ & $\begin{array}{l}\text { Girişimcili- } \\
\text { ğe yönelik } \\
\text { tutum }\end{array}$ & $\begin{array}{l}\text { Girişimci- } \\
\text { lik eğilimi }\end{array}$ \\
\hline & Sira Ort. & Sira Ort. & Stra Ort. & Sira Ort. & Sira Ort. \\
\hline \multicolumn{6}{|l|}{ Yaş } \\
\hline $18-29(1)$ & 558,60 & 536,86 & 540,39 & 552,44 & 550,75 \\
\hline $30-39(2)$ & 508,56 & 525,89 & 517,09 & 504,82 & 516,12 \\
\hline $40-49$ (3) & 475,72 & 480,73 & 477,15 & 457,33 & 468,39 \\
\hline $50-59(4)$ & 337,43 & 419,63 & 410,16 & 429,70 & 381,75 \\
\hline 59 ve üstü (5) & 293,61 & 267,37 & 302,77 & 306,51 & 289,35 \\
\hline KW & 70,836 & 53,824 & 44,936 & 49,411 & 58,598 \\
\hline$P$ & 0,000 & 0,000 & 0,000 & 0,000 & 0,000 \\
\hline Bonferroni & $\begin{array}{c}1>3,1>5, \\
2>5,3>5 \\
1>4,2>4,3>4\end{array}$ & $\begin{array}{c}1>4,1>5 \\
2>5,3>5,4>5\end{array}$ & $\begin{array}{l}1>4,1>5, \\
2>5,3>5\end{array}$ & $\begin{array}{c}1>4,1>3 \\
1>5,2>5,3>5\end{array}$ & $\begin{array}{l}1>4,1>3, \\
1>5,2>5, \\
3>5,3>4\end{array}$ \\
\hline \multicolumn{6}{|l|}{ Medeni Durum } \\
\hline Evli & 483,60 & 492,50 & 491,94 & 488,95 & 489,50 \\
\hline Bekar & 524,32 & 511,78 & 512,57 & 516,79 & 516,01 \\
\hline $\mathrm{U}$ & 111502,000 & 116706,500 & 116379,000 & 114628,500 & 114951,000 \\
\hline$P$ & 0,027 & 0,294 & 0,261 & 0,129 & 0,152 \\
\hline
\end{tabular}

Yerleşim Yeri 


\section{Zeliha Tekin}

\begin{tabular}{|c|c|c|c|c|c|}
\hline Merkez (1) & 488,40 & 483,30 & 496,22 & 489,84 & 486,95 \\
\hline Varto (2) & 497,86 & 501,08 & 477,16 & 470,26 & 501,26 \\
\hline Malazgirt (3) & 484,70 & 486,46 & 484,75 & 482,10 & 477,68 \\
\hline Bulanık (4) & 512,28 & 526,04 & 521,68 & 524,27 & 523,12 \\
\hline Korkut (5) & 497,21 & 490,65 & 442,45 & 474,45 & 462,10 \\
\hline Hasköy (6) & 606,32 & 582,22 & 581,08 & 601,17 & 609,10 \\
\hline KW & 10,711 & 8,975 & 9,860 & 12,038 & 13,556 \\
\hline$P$ & 0,057 & 0,110 & 0,079 & 0,034 & 0,019 \\
\hline Bonferroni & & & & $1>5$ & $6>3,6>1$ \\
\hline \multicolumn{6}{|c|}{ Sermaye yeterli- } \\
\hline \multicolumn{6}{|c|}{ liği } \\
\hline Evet & 481,44 & 455,77 & 439,22 & 454,12 & 457,19 \\
\hline Hayır & 501,52 & 502,90 & 503,79 & 502,99 & 502,83 \\
\hline $\mathrm{U}$ & 23227,500 & 21918,500 & 21074,000 & 21834,000 & 21990,500 \\
\hline$P$ & 0,627 & 0,252 & 0,116 & 0,234 & 0,271 \\
\hline \multicolumn{6}{|c|}{ Faaliyet gösteri- } \\
\hline \multicolumn{6}{|c|}{ len alan } \\
\hline Hayvancılık & 449,28 & 415,48 & 439,90 & 432,02 & 437,60 \\
\hline Tarım & 366,55 & 407,98 & 400,69 & 375,02 & 378,19 \\
\hline El işi, imalat & 422,82 & 430,39 & 425,53 & 428,54 & 426,24 \\
\hline Hizmet & 411,64 & 370,65 & 377,49 & 373,77 & 388,42 \\
\hline KW & 3,202 & 3,064 & 2,618 & 3,680 & 2,547 \\
\hline$P$ & 0,362 & 0,382 & 0,454 & 0,298 & 0,467 \\
\hline \multicolumn{6}{|c|}{$\begin{array}{l}\text { Kurs alma du- } \\
\text { rumu }\end{array}$} \\
\hline Evet & 541,08 & 531,86 & 525,51 & 526,82 & 534,95 \\
\hline Hayır & 472,88 & 479,16 & 483,47 & 482,59 & 477,05 \\
\hline $\mathrm{U}$ & 104053,000 & 107788,000 & 110356,500 & 109829,000 & 106537,000 \\
\hline$P$ & 0,000 & 0,004 & 0,022 & 0,016 & 0,002 \\
\hline \multicolumn{6}{|c|}{$\begin{array}{l}\text { Ailede girişimci } \\
\text { olma durumu }\end{array}$} \\
\hline Evet & 505,16 & 502,62 & 513,97 & 512,38 & 510,57 \\
\hline Hayır & 498,72 & 499,69 & 495,37 & 495,97 & 496,66 \\
\hline $\mathrm{U}$ & 98626,000 & 99328,000 & 96195,500 & 96633,000 & 97133,500 \\
\hline$P$ & 0,752 & 0,885 & 0,358 & 0,416 & 0,496 \\
\hline \multicolumn{6}{|l|}{$\begin{array}{l}\text { Aile bask1- } \\
\text { s1/Destekten } \\
\text { yoksunluk }\end{array}$} \\
\hline Evet & 477,43 & 487,43 & 490,68 & 482,00 & 483,77 \\
\hline Hayır & 536,28 & 520,77 & 515,73 & 529,19 & 526,45 \\
\hline $\mathrm{U}$ & 105141,000 & 296357,000 & 298335,500 & 293058,500 & 294131,000 \\
\hline$P$ & 0,002 & 0,072 & 0,176 & 0,011 & 0,022 \\
\hline \multicolumn{6}{|l|}{$\begin{array}{l}\text { Yeterli eğitim } \\
\text { olanaklarının } \\
\text { olmayışı }\end{array}$} \\
\hline Evet & 495,55 & 509,31 & 510,60 & 504,95 & 504,80 \\
\hline Hayır & 510,06 & 483,48 & 480,97 & 491,89 & 492,19 \\
\hline
\end{tabular}




\begin{tabular}{lccccc} 
U & 109100,000 & 106556,000 & 105701,000 & 109424,000 & 109524,500 \\
$P$ & 0,449 & 0,176 & 0,120 & 0,493 & 0,512 \\
\hline Maddi kaynak & & & & \\
eksikliği & & & & \\
Evet & 513,25 & 519,25 & 518,83 & 513,24 & 519,63 \\
Hayır & 469,89 & 455,47 & 456,49 & 469,91 & 454,55 \\
U & 94783,500 & 90543,000 & 90842,000 & 94788,000 & 90273,000 \\
$P$ & $\mathbf{0 , 0 3 0}$ & $\mathbf{0 , 0 0 1}$ & $\mathbf{0 , 0 0 2}$ & $\mathbf{0 , 0 2 9}$ & $\mathbf{0 , 0 0 1}$ \\
\hline Olumsuz iklim & & & & & \\
şartları & & & & \\
Evet & 489,48 & 512,62 & 511,20 & 503,69 & 505,06 \\
Hayır & 510,47 & 489,53 & 490,82 & 497,61 & 496,37 \\
U & 119453,500 & 118928,500 & 119606,000 & 123170,500 & 122521,500 \\
$P$ & 0,249 & 0,202 & 0,260 & 0,736 & 0,634 \\
\hline
\end{tabular}

Araştırma katılımcılarının girişimcilik eğilimi ölçeği ve alt boyutlarının yaşa göre farklılaşıp farklılaşmadığını belirlemek üzere, Kruskal Wallis $\mathrm{H}$ testi uygulanmıştır. Katılımcıların yaşa göre girişimcilik ölçeği alt boyutlarından girişimciliğe yönelik genel eğilim boyutunun istatistiksel açıdan anlamlı bir farklılık gösterdiği tespit edilmiştir ( $\mathrm{p}<0.05)$. 18-29 yaş grubunun girişimciliğe yönelik genel eğilimin, girişimciliğe yönelik algılanan sosyal norm boyutunun, girişimciliğe yönelik algılanan davranışsal kontrol boyutunun, girişimciliğe yönelik tutum boyutunun ve girişimcilik eğiliminin diğer yaş gruplarına göre daha yüksek olduğu görülmüştür. Yapılan Bonferroni testine göre farklılık yaratan gruplar tespit edilmiştir. Dolayısıyla 18-29 yaş olan grup $40-49$ yaş, $50-59$ yaş, 59 ve üstü yaş gruptan olanlardan, 30-39 yaş olan grup 50-59 yaş, 59 ve üstü yaş gruptan olanlardan, 40-49 yaş olan grup 50-59 yaş, 59 ve üstü yaş gruptan olanlardan farklıdır.

Katılımcıların medeni duruma göre girişimcilik eğilimi ölçeği ve alt boyutlarından girişimciliğe yönelik algılanan sosyal norm, girişimciliğe yönelik algılanan davranışsal kontrol, girişimciliğe yönelik tutum boyutlarının istatistiksel açıdan anlamlı bir farklılık göstermediği ancak girişimciliğe yönelik genel eğilim boyutunun istatistiksel açıdan anlamlı bir farklılık gösterdiği tespit edilmiştir. Buna göre bekâr olanların girişimciliğe yönelik genel eğiliminin evlilere göre daha yüksek olduğu görülmüştür.

Katılımcıların yerleşim yerine göre girişimcilik ölçeği alt boyutlarından girişimciliğe yönelik genel eğilim, girişimciliğe yönelik algılanan 
sosyal norm, girişimciliğe yönelik algılanan davranışsal kontrol boyutlarının istatistiksel açıdan anlamlı bir farklılık göstermediği buna karşılık girişimciliğe yönelik tutum boyutunun istatistiksel açıdan anlamlı bir farklılık gösterdiği tespit edilmiştir. Hasköy'de yaşayanların girişimciliğe yönelik tutumun diğer yerleşim yerlerine göre daha yüksek olduğu görülmüştür.

Katılımcıların kurs alma durumuna göre girişimcilik eğilimi ölçeği ve alt boyutlarından girişimciliğe yönelik genel eğilim, girişimciliğe yönelik algılanan sosyal norm, girişimciliğe yönelik algılanan davranışsal kontrol, girişimciliğe yönelik tutum boyutlarının istatistiksel açıdan anlamlı bir farklılık gösterdiği tespit edilmiştir. Buna göre girişimcilik ile ilgili bir kurs alanların girişimciliğe yönelik genel eğilimi, girişimciliğe yönelik algılanan sosyal normu, girişimciliğe yönelik algılanana davranışsal kontrolü, girişimciliğe yönelik tutumu ve girişimcilik eğilimi kurs almayanlara göre daha yüksek olduğu görülmüştür. Buna karşılık katılımc1ların ailede girişimci olma durumuna göre girişimcilik eğilimi ölçeği ve alt boyutlarının istatistiksel açıdan anlamlı bir farklılık göstermediği tespit edilmiştir.

Araştırmaya katılan bayanların girişimcilik eğilimi ölçeği ve alt boyutlarının aile baskısı/destekten yoksunluğa göre farklılaşıp farklılaşmadığını belirlemek üzere, Mann-Whitney U testi uygulanmıştır. Katılımc1ların aile baskısı/destekten yoksunluğa göre girişimcilik eğilimi ölçeği alt boyutlarından girişimciliğe yönelik algılanan sosyal norm ve girişimciliğe yönelik algılanan davranışsal kontrol boyutlarının istatistiksel açıdan anlamlı bir farklılık göstermediği tespit edilmiştir. Katılımcların aile baskıs1/destekten yoksunluğa göre girişimcilik eğilimi ölçeği ve alt boyutlarından girişimciliğe yönelik genel eğilim ve girişimciliğe yönelik tutum boyutlarının istatistiksel açıdan anlamlı bir farklılık gösterdiği tespit edilmiştir. Buna göre Muş'ta kadın girişimcilerin karşılaştığı zorluklar arasında aile baskısı/destekten yoksunluğun olmadığını düşünenlerin girişimciliğe yönelik genel eğilimi, girişimciliğe yönelik tutumu ve girişimcilik eğilimi Muş'ta kadın girişimcilerin karşılaştığı zorluklar arasinda aile baskısı/destekten yoksunluğun olduğunu düşünenlere göre daha yüksek olduğu görülmüştür.

Araştırmaya katılanların girişimcilik eğilimi ölçeği ve alt boyutlarının yeterli eğitim olanaklarının olmayışına göre farklılaşıp farklılaşmadığını 
belirlemek üzere, Mann-Whitney U testi uygulanmıştır. Katılımcıların yeterli eğitim olanaklarının olmayışına göre girişimcilik eğilimi ölçeği ve alt boyutlarının istatistiksel açıdan anlamlı bir farklılık göstermediği tespit edilmiştir.

Araştırmaya katılanların girişimcilik eğilimi ölçeği ve alt boyutlarının maddi kaynak eksikliğine göre farklılaşıp farklılaşmadığını belirlemek üzere, Mann-Whitney U testi uygulanmıştır. Katılımcların maddi kaynak eksikliğine göre girişimcilik eğilimi ölçeği ve alt boyutlarının istatistiksel açıdan anlamlı bir farklılık gösterdiği tespit edilmiştir. Buna göre Muş'ta kadın girişimcilerin karşılaştığı zorluklar arasında maddi kaynak eksikliğinin olduğunu düşünenlerin girişimciliğe yönelik genel eğilimi, girişimciliğe yönelik algılanan sosyal normu, girişimciliğe yönelik alg1lanan davranışsal kontrolü, girişimciliğe yönelik tutumu ve girişimcilik eğilimi Muş'ta kadın girişimcilerin karşılaştığı zorluklar arasında maddi kaynak eksikliğinin olmadığını düşünenlere göre daha yüksek olduğu görülmüştür.

Araştırmaya katılanların girişimcilik eğilimi ölçeği ve alt boyutlarının olumsuz doğa şartlarına göre farklılaşıp farklılaşmadığını belirlemek üzere, Mann-Whitney U testi uygulanmıştır. Katılımcıların olumsuz doğa şartlarına göre girişimcilik eğilimi ölçeği ve alt boyutlarının istatistiksel açıdan anlamlı bir farklılık göstermediği tespit edilmiştir.

\section{Sonuç ve Öneriler}

Muş ilinde yürütülen bu çalışma ile kadınların hanelerine gelir sağlamak amacıyla (kayıt altına alınmamış) pek çok iş yaptıkları, çoğunluğun imkân verildiği/yatırım ortamı oluşturulduğu takdirde iş yeri sahibi olmak istedikleri ortaya çıkmıştır. Çalışmada 18-29 yaş grubundakilerin diğer yaş gruplarına, bekâr olanların evlilere ve girişimcilik ile ilgili bir kurs alanların almayanlara göre girişimciliğe yönelik genel eğilimin, girişimciliğe yönelik algılanan sosyal norm boyutunun, girişimciliğe yönelik algılanan davranışsal kontrol boyutunun, girişimciliğe yönelik tutum boyutunun ve girişimcilik eğiliminin daha yüksek olduğu sonucuna varılmıştır.

Araştırmaya dâhil olan kadınların ankete verdikleri cevaplara bakıldığında, Muş'ta inşaat işleri, kaynakçılık, araba tamiri, marangoz- 
luk, elektrik işleri (erkek işi olarak algılama); öğretmenlik, hemşirelik, terzilik, aşçılık, sekreterlik (kadın işi olarak algılama) gibi mesleklerde cinsiyet-rol stereotiplerinin (kalıp yargı) olduğu anlaşılmaktadır. Toplumsal alandaki işlerin "erkek işi" ve "kadın işi” olarak eril veya dişil sinıflandırılması toplumsal cinsiyet stereotipleri olarak adlandırılır. Örneğin mühendislik, imalat ve inşaat faaliyetleri eril özellik taşırken, hizmet sektörü, halkla ilişkiler, eğitim, danışmanlık, hemşirelik faaliyetleri büyük ölçüde dişil özelliktedir (Antalyalı ve Özkul, 2017: 4). Türkiye'deki toplumsal inanış kadınların meslek seçerken fazla sorumluluk gerektirmeyen, zaman almayan "kadın işi” sayılan öğretmenlik, eczacılık gibi meslekleri seçmeleri yönündedir. Günümüzde girişimcilik tanımlaması da yapılırken sosyokültürel stereotiplerin göz önünde bulundurulması gereken bir unsur olduğu aşikârdır. Örneğin, kadın girişimcilerden, erkeklere oranla daha az sermaye gerektiren, daha küçük çaplı, yavaş büyüyen (çoğunlukla da hizmet ve perakende sektörü) işler seçmeleri/işler kurmaları beklenmektedir (Antalyalı ve Özkul, 2017: 4).

Araştırmada proje kapsamı gereği anket soruları, kadın girişimci adaylarına sorulmuş ve veriler yorumlanmıştır. Ancak "Muş'ta kadınlar çalışma hayatında hangi iş/sektörlerde yoğunlaşmışlardır?"; "Muş'taki kadınların hane içinde gerçekleştirdiği işlerle hangi tip işletmeler kurulabilir?"; "Muş'ta hangi sektörler/meslekler kadın girişimciliğine açıktır?" gibi sorulara da kadın girişimciliğin gelişmesi, mevcut sorunların tespiti ve çözüm yollarının bulunması açısından cevap aranmıştır. Bu amaçtan hareketle Muş Ticaret ve Sanayi Odasından, Halk Eğitim Merkezlerinden, Sosyal Destek Programı (SODES) kursiyerlerinden bilgi edinilmiştir. MUŞ Ticaret ve Sanayi Odasına kayıtlı 1750 işletmenin varlığına karşın bu işletmelerin yalnızca 128'inin kadın işletmeciye (ortaklık şeklinde) ait olduğu ve bu işletmelerden 30'unun bayan işletmeci tarafından işletildiği verilerine ulaşılmıştır. Kadın işletmeciler sırasıyla en çok, sigortacılık hayvan yetiştiriciliği, tarım, süt ve süt ürünleri, peynircilik işleme/satış, tekstilkonfeksiyon, gelinlik/kuaför, sürücü kursu işletme, inşaat/emlak işleriyle uğraşmaktadır. Halk eğitim ve SODES kursiyerlerinden edinilen bilgilere göre de boncuk ve dantel oyacılı̆̆ı, çorap örmeciliği, halı-kilim dokumacılığı gibi geleneksel el sanatları haneye gelir getirmesi açısından ve kadın girişimciliğinin geliştirilmesi açısından devletçe desteklenmesi de gereken ev hanımlarının en önemli uğraşlarındandır. 
$\mathrm{Bu}$ çalışmanın diğer illerde yapılmış olan benzer çalışmalarla birlikte değerlendirildiği zaman Türkiye'nin kadın girişimciliğinin özelliklerini ve kadın girişimcilik kültür yapısını anlamaya ve girişimcilikteki genel cinsiyet-rol stereotiplerinin ortaya çıkararak bütüncül bir bakış açısı kazandırmaya katkı sağlayabileceği düşünülmektedir. 
EXTENDED ABSTRACT

\title{
Women's Entrepreneurship and Sex-Role Stereotypes: Muş Province Example
}

\author{
Zeliha Tekin \\ Muş AlparslanUniversity
}

The development and sustainability of a country's economy and its creation of employment opportunities and reducing unemployment, in short, increasing the level of prosperity depend on its use of its potential such as natural resources, physical capital and human capital. One of the factors that can trigger this potential is women's entrepreneurship. Women's entrepreneurship is a topic that needs to be focused and improved, as it allows to increase the development potential and create more jobs. Although women's participation in labor force is in different ways, women's participation in labor life has been concentrated in certain professions in Turkey and in the world under the influence of gender-role stereotypes. The separation of the professions in social life as feminine and masculine is expressed as gender stereotypes. For example, construction works, management works, engineering and manufacturing works are considered as men's jobs, while nursing, secretary and training consultancy works are considered as women's jobs. This type of stereotypical discrimination reflects gender discrimination in the workplace.

The aim of the study is to identify the entrepreneurship profile of women entrepreneur candidates in Muss and the areas in which they operate, taking into account the demographic characteristics of them, and determine the gender-role stereotypes in which professions they operate.

\section{Method}

The target population of the study is women who reside in Mus and make money at home to contribute to household income (such as looking after children, doing hand work, selling cheese, milk, fruits and vegeta- 
bles). The sample of the research consists of 1000 women who reside in the Mus city center and districts selected by stratified sampling method. Questionnaire technique was used as data collection technique in this study. In this study, the "entrepreneur tendency scale" with 17 expressions of 4 dimensions which is formed by Uygun and Güner (2016) by scanning the literature was used. Survey questions consist of two parts. The questions in the first part are open-ended and multiple choice and aim to determine the demographic characteristics of the responders. The questions in second part aim at measuring the entrepreneurial tendency of the participants and are created using the 5- point Likert-type scale.

\section{Results}

The majority of participating women (434 people) are 18-29 years old and more than half are married (585 people). In order to comment on women's entrepreneurship in Turkey, the rate of schooling needs to be taken into consideration. When the educational status of the participants is examined, it is seen that the majority is primary school graduates (406 people). Almost all participants (949 people) do not have the capital to start a business. Only 51 out of 1,000 participating women have enough capital to start a business. While 405 of the participants received an education on entrepreneurship; 595 has not received any training on entrepreneurship, and 276 of them have entrepreneurs in their family while 724 do not have entrepreneurs in their family. More than half of the participants (645 people) are engaged in handicraft works such as sewing, carpet weaving and knitting. Despite the existence of Muş plain, which is Turkey's third largest plain in one piece with an area of 165000 hectares and a length of $80 \mathrm{~km}$ and a width of $30 \mathrm{~km}$, only 31 of the women who responded to the survey are engaged in agriculture and 124 people are interested in animal husbandry. This study in Muş province revealed that women do many jobs (not registered) in order to provide income to their households, and they want to have a place of work if the majority of them are allowed/investment environment is established. One of the problems that women entrepreneurs think exists in terms of entrepreneurship activities is the lack of material resources (706 people). In addition, other negative factors such as lack of adequate educational facilities 
(659 people), family pressure-lack of adequate support from family to start a business (608 people), presence of gender inequality (567 people) should not be underestimated. It was found that the overall trend towards entrepreneurship from the sub-dimensions of the participants' age scale differs statistically $(p<0.05)$. The study concluded that the general tendency towards entrepreneurship, the perceived social norm dimension towards entrepreneurship, the behavioral control dimension perceived towards entrepreneurship, the attitude dimension towards entrepreneurship and the entrepreneurial tendency are higher in the 18-29 age group compared to others; in the singles compared to the married ones and in those who take a course on entrepreneurship compared to those who do not take a course on entrepreneurship.

\section{Conclusion}

As a result of the research, it has been revealed that women want to have a place of business if they are allowed or an investment environment is created. The study also concluded that entrepreneurship trends, general trends towards entrepreneurship, perceived social norm levels of entrepreneurship and entrepreneurial attitudes of women who have an entrepreneurship training were higher than other status groups: it has been observed that there are gender stereotypes in occupations such as construction works, welding, car repair, carpentry and electrical works.

\section{Kaynakça/References}

Bacacı V. D. (2001). Yönetim ve organizasyon içinde “Örgütsel yaşamda toplumsal cinsiyet rolleri", Ed: Salih Güney, Ankara: Nobel Yayincilik.

Bora, A. (2008). Sivil toplum kuruluşları için toplumsal Cinsiyet rehberi, Ankara: Odak Ofset Matbaacilik.

Cherry, A. L. (2005). Examining global social welfare, Issues, Thomson Brooks/Cole, Belmont.

Delphy, C. (1993). Rethinking sex and gender, Women's Studies Int. Forum, 16 (1), 1-9. 
Dökmen, Z. Y. (2004). Toplumsal psikolojik açıklamalar, Ankara: Sistem Yayıncilik.

Gupta, V., Turban, D. B., Wasti, A. S., ve Sikdar, A. (2009). The role of gender stereotypes in perceptions of entrepreneurs and intentions to become an entrepreneur, Entrepreneurship Theory and Practice, 33(2), 397-417.

Güney, S. (2015). Girişimcilik: Temel kavramlar ve bazı güncel konular, Ankara: Siyasal Kitabevi.

Herrera, B. G. C., ve Lankau, M. J. (2005). Are we there yet? An assessment of fit between stereotypes of minority managers and the successful manager prototype, Journal of Applied Social Psychology, 35(10), 20292056.

Ickes, W. (1993). Traditional gender roles: Do they make, and then break, our relationships? Journal of Social Issues, 49 (3), 71-85.

Navaro, L. (1997). Tapınağın öbür yüzü, İstanbul: Varlık Yayınları.

Newman, L. K. (2002). Sex, gender and culture: Issues in the definition, assessment and treatment of gender identity disorder, Clinical Child Psychology and Psychiatryy, 7, 358-367.

Oakley, A. (1985). Sex, gender and society. London: Temple Smith.

Saray, G. (1993). Türkiye'de kadın girişimciliği, kadını girişimciliğe özendirme ve destekleme paneli, Ankara.

Seçgin, F., ve Tural, A. (2011). Sınıf öğretmenliği bölümü öğretmen adaylarının toplumsal cinsiyet rollerine ilişkin tutumları, e-Journal of New World Sciences Academy Education Sciences, 6 (4), 2446.

Zara, A., ve Burçak Özdemir, B. (2013). Kadınların yaşamı ve kadın ruh sağlığı içinde "Cinsiyet rolleri", Ed: Şahika Yüksel Leyla Gülseren Ayşe Devrim Başterzi, Ankara: Türkiye Psikiyatri Derneği Kadın Ruh Sağlığı Çalışma Birimi Dizisi, No:16.

www.sozcu.com.tr: Kadınları erkeklerden ayıran özellikler nelerdir?

\section{Kaynakça Bilgisi / Citation Information}

Tekin. Z. (2018). Kadın girişimciliği ve cinsiyet-rol stereotipleri: Muş ili örneği. OPUS-Uluslararası Toplum Araştırmaları Dergisi, 9(16), 10911113. DOI: $10.26466 /$ opus. 453934 